\title{
5-Azacytidine Acts Directly on Both Erythroid Precursors and Progenitors to Increase Production of Fetal Hemoglobin
}

\author{
R. Keith Humphries, George Dover, Neal S. Young, Jeffrey G. Moore, Samuel Charache, \\ Timothy Ley, and Arthur W. Nienhuis \\ Clinical Hematology Branch, National Heart, Lung, and Blood Institute, National Institutes of Health, Bethesda, Maryland 20205; \\ Departments of Pediatrics and Medicine, Johns Hopkins University, Baltimore, Maryland 21218
}

\section{Abstract}

The effect of 5-azacytidine on erythroid precursors and progenitors was studied in nine patients with sickle cell anemia or severe thalassemia. Each patient received the drug intravenously for 5 or $7 \mathrm{~d}$. 5-Azacytidine caused a four- to sixfold increase in $\boldsymbol{\gamma}$-messenger RNA concentration in bone marrow cells of eight of the nine patients and decreased the methylation frequency of a specific cytosine residue in the $\gamma$-globin gene promoter in all nine patients. Within $2 \mathrm{~d}$ of the start of drug treatment there was a rise in the percentage of reticulocytes containing fetal hemoglobin (HbF; F-reticulocytes) without a significant change in the total number of reticulocytes, which suggested that there was a direct action of 5-azacytidine on erythroid precursors. Late erythroid progenitors (CFU-E), present in bone marrow after $\mathbf{2} \mathbf{d}$ of drug administration, formed colonies containing an increased amount of $\mathrm{HbF}$ as compared with control colonies. Moreover, the number of CFU-E derived colonies was not decreased at these early times, which suggested that there was a direct action of 5azacytidine on erythroid progenitors in the absence of cytotoxicity. Exposure of normal bone marrow cells in tissue culture to 5-azacytidine for $24 \mathrm{~h}$ reproduced both of these effects as judged during subsequent colony formation. The combined direct effects of 5-azacytidine on both the erythroid precursor and progenitor compartments resulted in an increase in $\mathbf{H b F}$ synthesis that was sustained for 2-3 wk. Toxicity to bone marrow as reflected by cytoreduction was evident after treatment in some patients but was not accompanied by an increase in HbF production. A correlation was found between the effects of 5-azacytidine on bone marrow, as assessed by in vitro measurements, and the hematological response of the individual patients to drug treatment.

\section{Introduction}

The severe hemoglobinopathies or $\beta$-thalassemias reflect alterations in the structure or function of the $\beta$-globin gene, respectively. The onset of these genetic disorders of hemoglobin occur after the perinatal switch from fetal hemoglobin (HbF) ${ }^{\prime}$

Dr. Humphries' current address is the British Columbia Cancer Research Center, Vancouver, British Columbia, Canada.

Received for publication 18 April 1984 and in revised form 21 September 1984.

1. Abbreviations used in this paper: BFU-E, primitive erythroid progenitor(s), burst-forming unit(s); CFU-E, late erythroid progenitor(s); FCS, fetal calf serum; HbF, fetal hemoglobin; IMDM, Iscove's modification of Dulbecco's medium; kb, kilobases.

The Journal of Clinical Investigation, Inc.

Volume 75, February 1985, 547-557 $\left(\alpha_{2} \gamma_{2}\right)$ to $\mathrm{HbA}\left(\alpha_{2} \beta_{2}\right)$ production as $\beta$-globin synthesis replaces $\gamma$-globin synthesis. Reactivation of the globin genes with replacement of the defective $\beta^{S}$ chain, or as compensation for deficient $\beta$-synthesis, could be effective treatment for sickle cell anemia or the $\beta$-thalassemias.

Normal humans produce a low level of $\mathrm{HbF}$ after the first year of life. Usually $\leq 1 \%$ of the total hemoglobin is $\mathrm{HbF}$ and it is restricted to a small proportion of the total erythrocytes called F-cells (1). The formation of F-cells appears to be modulated during both erythroid precursor and progenitor development. There is asynchronous synthesis of $\mathrm{HbF}$ and $\mathrm{HbA}$ during erythroblast maturation; fetal hemoglobin is produced predominantly in the early pro- and basophilic erythroblasts (2-4). Erythroid progenitors from adult bone marrow form colonies of erythroblasts containing substantially more $\mathrm{HbF}$ than is found in vivo (5). The erythroid colonies produced in culture from progenitors of a single individual produce highly variable amounts of $\mathrm{HbF}(6-9)$. This evidence that modulation of $\mathrm{HbF}$ synthesis also occurs during progenitor differentiation, and the clinical observation that $\mathrm{HbF}$ synthesis increases transiently after bone marrow transplantation or recovery from erythroblastopenia $(10,11)$ suggests that $\mathrm{HbF}$ synthesis might be reactivated with appropriate stimuli in patients with mutations in the $\beta$-globin genes.

Several molecular correlates of hemoglobin switching have been defined. Regulation appears to occur at the level of gene transcription (12). There are changes in chromatin structure as reflected by the disappearance of nuclease-sensitive sites immediately upstream from the $\gamma$-globin genes when these genes are switched off during development (13). The cytosine residues in this region are relatively undermethylated during $\gamma$-gene expression in the fetus but become fully methylated in adult bone marrow, where the $\gamma$-globin genes are repressed (14). The latter observation prompted the use of 5-azacytidine, a cytosine analogue that inhibits the enzymatic methylation of newly synthesized DNA, in an effort to activate the globin genes, first in experimental animals (15) and later in humans (16-18).

Administration of 5-azacytidine led to a nearly complete switch from adult to fetal hemoglobin synthesis in baboons and a substantial increase in HbF synthesis in humans. This increase in $\mathrm{HbF}$ production was accompanied by improved production of erythrocytes in thalassemic patients (16) and by a reduction in sickling propensity of the erythrocytes in patients with sickle cell anemia (17). Reduced methylation upstream from the $\gamma$-gene accompanied the increase in $\gamma$ globin gene expression (16-18). Although the reduction in methylation was a global effect in that many cytosine residues showed decreased methylation frequency, only the $\gamma$-globin gene among several genes assayed showed a significant increase in expression. 
This unexplained specificity, together with the known cytotoxic effects of the drug, suggested a mechanism of action for 5-azacytidine independent of its direct effects on DNA methylation. Recent experimental studies in baboons have shown that 5-azacytidine is cytotoxic to progenitors, leading to the hypothesis that the increase in $\mathrm{HbF}$ production occurs in part due to regeneration from earlier erythroid progenitors with a higher likelihood of forming erythroblasts that make HbF (19). That hydroxyurea, a cytotoxic drug with no known direct effects on DNA methylation, increases HbF synthesis in anemic monkeys has been interpreted as supporting this type of mechanism (20).

Our studies on the effect of 5-azacytidine in humans have included a detailed examination of the effect of this drug on erythroid progenitors and precursors. In this paper we describe the cellular and molecular data obtained from the study of nine patients, and these results are correlated with the clinical response of each individual patient. The results imply a complex mechanism of action but suggest that the response to 5-azacytidine is at least in part due to a direct noncytotoxic effect of the drug on erythroid precursors and progenitors.

\section{Methods}

\section{Characteristics of patients studied}

Nine patients were studied in detail. Each was over the age of $21 \mathrm{yr}$ and had either sickle cell anemia or severe (homozygous) $\beta$-thalassemia (Table I). Detailed clinical descriptions of patients $1-5$ have been previously published $(16,17)$. Patients 6-9 had a severe sickle syndrome with incapacitating chronic pain, intermittent acute pain crisis, and a significant transfusional iron burden with secondary hemochromatosis. Limited data are also presented on three additional patients with sickle cell anemia treated at Johns Hopkins Hospital, Baltimore, MD; their clinical features have been $(18,21)$, or will be, described in detail elsewhere.

Table I. Characteristics of Patients Studied

\begin{tabular}{llllc}
\hline No. & Patient & Age & Diagnosis & $\begin{array}{c}\text { Treatment } \\
\text { regimen* }\end{array}$ \\
\hline 1 & J.S. & 58 & Sickle cell anemia & A \\
2 & M.G. & 42 & Sickle cell anemia & A \\
3 & T.A. & 22 & Beta thalassemia & A \\
4 & R.R. & 22 & Beta thalassemia & A \\
5 & C.H. & 42 & Beta thalassemia & B \\
6 & W.J. & 31 & Sickle cell anemia & B \\
7 & A.L. & 39 & Sickle cell anemia & B \\
8 & J.I. & 31 & Sickle cell anemia & B \\
9 & W.J.J. & 40 & Sickle cell anemia & 1. B \\
& & & & 2. A \\
10 & J.P. & 34 & Sickle cell anemia & C \\
11 & D.P. & 28 & Sickle cell anemia & C \\
12 & W.T. & 36 & Sickle cell anemia & C \\
\hline
\end{tabular}

The treatment course for patients 1-4 (17), an earlier used course for patient $5(16)$, and the clinical response of patient $10(18)$ have been reported in detail previously. For patients $1-4$ and 6-9, the treatment course described was the first the patient received. Patient 5 had received another course of therapy 6 mo earlier.

* A, $2 \mathrm{mg} / \mathrm{kg}$ per $\mathrm{d}$ given by continuous intravenous infusion for $7 \mathrm{~d}$. B, $1.5 \mathrm{mg} / \mathrm{kg}$ per d given over $8 \mathrm{~h}$ for $5 \mathrm{~d} . \mathrm{C}, 2 \mathrm{mg} / \mathrm{kg}$ per d given for $3 \mathrm{~d}$ by bolus injection in divided doses every $8 \mathrm{~h}$. ¥ This patient received two treatment courses separated by several months.
The protocol for drug administration was approved by the National Heart, Lung, and Blood Institute Review Board and informed consent was obtained. Two treatment regimens were used. Patients treated with regimen $\mathrm{A}$ received 5-azacytidine $(2 \mathrm{mg} / \mathrm{kg}$ per d) by continuous infusion for $7 \mathrm{~d}$ as described previously $(16,17)$. Patients treated with regimen $B$ received a single, daily intravenous infusion of 5-azacytidine $(1.5 \mathrm{mg} / \mathrm{kg}$ per d) over $8 \mathrm{~h}$ for 5 successive days. Three patients treated at Johns Hopkins Hospital received $2 \mathrm{mg} / \mathrm{kg}$ per d given in divided doses intravenously at 8-h intervals (regimen C). Several patients experienced mild to moderate nausea and vomiting which was controlled with antiemetics, but no other significant side effects were observed.

After informed consent was obtained, hematologically normal volunteers donated bone marrow for various in vitro studies. A protocol for obtaining bone marrow from normal individuals was approved by the National Heart, Lung, and Blood Institute Review Board.

\section{DNA and RNA analysis}

RNA and DNA were recovered from bone marrow cells after lysis in guanadinium $\mathrm{HCl} /$ sarcosyl as previously described (22). RNA was analyzed with $S_{1}$ mapping (23) or primer extension techniques (24). For $S_{1}$ mapping, total bone marrow RNA was annealed to uniformly radiolabeled DNA probes prepared on single stranded templates of M13mp7- $\gamma$ or $\beta$-globin gene recombinants as previously described (25). Hybridization and $S_{1}$ digestion conditions followed published protocols (23). After $S_{1}$ nuclease digestion, samples were precipitated with ethanol, heat denatured, and analyzed on $8 \%$ polyacrylamide sequencing gels with subsequent autoradiography (26). $\alpha$-globin mRNA was analyzed by primer extension by use of an oligonucleotide primer (P-L Biochemicals, Inc., Milwaukee, WI) corresponding to nucleotides 97 through $1153^{\prime}$ to the cap site. The primer was $5^{\prime}$-labeled by the use of polynucleotide kinase and purified by published techniques (27). The radiolabeled probe and RNA were coprecipitated and lyophilized. After primer extension with reverse transcriptase, extended products were resolved on $8 \%$ polyacrylamide sequencing gels. Densitometric analysis of radiographs provided a quantitative estimate of relative mRNA concentrations.

The frequency of cytosine methylation near the $\gamma$-globin genes was ascertained by restriction enzyme analysis. Total bone marrow DNA was first digested to completion with the enzyme Eco RI and then further digested with a fivefold excess of the enzyme Hpall $(14,16$, 17). The latter enzyme cleaves only if the internal cytosine of the DNA sequence recognized by HpaII [CCGG] is unmethylated. Restriction enzymes were obtained from Bethesda Research Labortories (Gaithersburg, MD) and used according to the manufacturer's recommendations. Completeness of digestion was determined by standard techniques. After double digestion, samples were electrophoresed on $1 \%$ agarose vertical slab gels and DNA was transferred to nitrocellulose filters by the technique of Southern (28). Filters were baked, prehybridized, and washed as previously described (29). Filters were then autoradiographed at $-70^{\circ} \mathrm{C}$ by the use of intensifying screens.

\section{Analysis of $\mathrm{HbF}$}

Total $\mathrm{HbF}$. HbF in peripheral blood was determined from the percentage in hemolysates as measured by alkaline denaturation (30) and reference to total hemoglobin levels.

$F$-reticulocytes. Reticulocytes containing $\mathrm{HbF}$ were defined by microscopic immunoprecipitate reactions by use of rabbit anti-human $\mathrm{HbF}$ antibody as described in detail elsewhere (31). The absolute concentration of F-reticulocytes was calculated by determination of the percentage of total reticulocytes in peripheral blood smears, stained with new methylene blue, and by determination of the red cell count with a Coulter counter (Coulter Electronics Inc., Hialeah, FL).

$H b F$ content of individual erythroid cells. Microscopic immunoprecipitate reactions were also used to determine the percentage of nucleated erythroid cells containing $\mathrm{HbF}$ and the amount of $\mathrm{HbF}$ in individual erythroid cells present in erythroid colonies grown in vitro 
(7, 31). In brief, maximally hemoglobinized colonies derived from mature or primitive erythroid progenitors were plucked, washed, and pooled as described below. Cells were washed three times in buffered saline and dispersed into single cells and mixed with agarose, new methylene blue, and antibody to either human $\mathrm{HbF}$ or adult hemoglobin. The agarose suspension was placed on glass slides, the cells were lysed with $0.2 \%$ Triton $\mathrm{X}-100$, and the percentage of cells with $\mathrm{HbF}$ anti-HbF or $\mathrm{HbA}$-anti-HbA pericellular immunoprecipitate reactions was enumerated. The amount of $\mathrm{HbF}$ or $\mathrm{HbA}$ in individual nucleated cells was quantitated microdensitometrically.

\section{Culture of erythroid progenitors}

Bone marrow cells aspirated from the posterior iliac crest were drawn into Iscove's modification of Dulbecco's medium (IMDM; Flow Laboratories, McLean, Virginia) with $50 \mathrm{U} / \mathrm{ml}$ of preservative-free heparin (O’Neal, Jones \& Feldman, St. Louis, MO). Mononuclear cells were separated by Percoll (Pharmacia Fine Chemicals, Piscataway, NJ) sedimentation according to the manufacturer's directions followed by two washes in IMDM-2\% heat inactivated $\left(56^{\circ} \mathrm{C}, 30 \mathrm{~min}\right)$ fetal calf serum (FCS; Flow Laboratories) at a final concentration of $1 \times 10^{5}$ cells $/ \mathrm{ml}$. Erythroid progenitors culture were assayed in medium containing $0.8 \%$ methylcellulose (Dow Chemical Company, Midland, Michigan), 30\% FCS, $1 \%$ bovine serum albumin (BSA; Sigma Chemical Co., St. Louis, Missouri); $100 \mathrm{U} / \mathrm{ml}$ penicillin/streptomycin (MA Bioproducts, Walkerville, Maryland); $2.5 \mathrm{U} / \mathrm{ml}$ of erythropoietin (Connaught Laboratories, Willowdale, Ontario), and $10 \%$ phytohemagglutinin (Gibco Laboratories, Grand Island, New York) stimulated leukocyteconditioned media. Cultures were incubated at $37^{\circ} \mathrm{C}$ in $95 \%$ humidity and $5 \% \mathrm{CO}_{2}$. Erythroid progenitor types were assayed by their distinctive colony-forming characteristics as follows: colonies derived from the late erythroid progenitor (CFU-E) were counted on day 8 and characterized by a single cluster of well-hemoglobinized cells; colonies derived from more primitive erythroid progenitors, burst-forming units (BFUE), were scored on day 18 and characterized as consisting of three or more clusters of well-hemoglobinized cells (32). In our laboratory the number of colonies in cultures of $10^{5}$ normal bone marrow mononuclear cells is as follows: CFU-E derived, $93 \pm 11$, and BFU-E derived, 104 \pm 11 (mean \pm SEM, $n=22$ ).

For determination of $\mathrm{HbF}$ content of individual erythroid cells contained in erythroid colonies, mature well-hemoglobinized colonies were plucked on day 8 (CFU-E derived colonies) or day 18 (BFU-E derived colonies) under microscopic visualization by use of a tapered Pasteur pipette. Analysis of BFU-E derived colonies was restricted to those derived from the most primitive progenitors by plucking of only those colonies consisting of $>16$ clusters (32). Approximately $50 \mathrm{CFU}$ E derived colonies or 5-10 primitive BFU-E derived colonies were pooled, gently resuspended, and washed in buffered saline, and $\mathrm{HbF}$ was measured as described above.

In vitro treatment with 5-azacytidine. Bone marrow mononuclear cells from normal volunteers, separated by Percoll density sedimentation, were added at a final concentration of $2 \times 10^{6}$ cells $/ \mathrm{ml}$ to liquid cultures containing 5-azacytidine at concentrations from 0.1 to $10 \mu \mathrm{g} /$ $\mathrm{ml}$ in $30 \% \mathrm{FCS}, 1 \% \mathrm{BSA}, 10^{-4} \mathrm{M} \beta$-mercaptoethanol without erythropoietin, or $10 \%$ phytohemagglutinin-stimulated leukocyte-conditioned medium in IMDM at $37^{\circ} \mathrm{C}$. To maintain 5-azacytidine concentrations, additional 5 -azacytidine was added 8 and $16 \mathrm{~h}$ after initiation of incubation. After $24 \mathrm{~h}$, cells were washed and replated in standard methylcellulose culture (see above) at $1 \times 10^{5} \mathrm{cells} / \mathrm{ml}$ in the absence of 5-azacytidine. CFU-E derived colonies were scored $8 \mathrm{~d}$ later. The $\mathrm{HbF}$ content of individual erythroblasts in these colonies was determined by radial immunodiffusion as described above.

\section{Results}

\section{Molecular effects of 5-azacytidine}

Messenger RNA. The relative content of $\gamma$-messenger RNA (mRNA) in bone marrow erythroblasts was measured by $S_{1}$ nuclease analyses. To compare individual bone marrow samples, $\gamma$-mRNA levels were normalized to $\alpha$ - or $\beta$-mRNA content as measured by primer extension or $S_{1}$ nuclease analysis, respectively. The data shown in Fig. $1 A$ were derived from an analyses of bone marrow samples obtained from patient 7 on day 0,2 , or 7 . Relative to the pretreatment day 0 value, $\gamma$-mRNA content was increased 1.4-fold on day 2 and 5.9-fold on day 7 as determined by demisometric analyses of the radioautographs. An increase in $\gamma$-mRNA content was documented on day 2 in three patients studied and on day 7 in all patients (data not shown), with the exception of patient 9. For this patient, during the first course of treatment, there was a small increase in $\gamma$-mRNA content $(1.5 \times)$ on day 7 as compared with control obtained on day 0 , but there was no detectable increase in $\gamma$-mRNA content during the second course on day 3 as compared with the day 0 bone marrow RNA sample (Fig. $1 \mathrm{~B}$ ).

Methylation. A decrease in the frequency of methylation at several sites within the $\beta$-like gene cluster was documented by restriction endonuclease analysis and Southern blotting as previously described $(14,16)$. A representative analysis of the methylation site immediately $5^{\prime}$ to the $G_{\gamma^{-}}$and $A_{\gamma}$-genes for bone marrow DNA samples from patient 9 is shown in Fig. 2. Double digestion of DNA with the enzymes Eco RI and HpalI will yield a 1.5-kilobase fragment if DNA is unmethylated at the Hpall site. A decrease in the frequency of methylation as compared with that of the control DNA samples was apparent upon visual inspection and scanning of the radioautographs of Southern blots in the day 7 bone marrow sample from the first course and in the day 3 bone marrow sample from the second course. Similar data were obtained on analyses of DNA from all patients (references 16 and 17, and data not shown).

\section{Effects of 5-azacytidine on erythroid cells}

Reticulocytes. Reticulocytes containing HbF (F-reticulocytes) were enumerated to provide an index of the early effect of 5azacytidine on erythroid cells. By $7 \mathrm{~d}$, five patients studied in detail showed a 3- to 10-fold increase in percentage of Freticulocytes (Fig. 3). For 3 of 5 patients, a striking increase was evident after only $24 \mathrm{~h}$ of treatment; the other two showed a more gradual increase. This increment in the percentage of F-reticulocytes occurred without a significant change in the absolute reticulocyte count (mean pretreatment, $3.3 \times 10^{5}$ vs. mean day 2-4, $3.1 \times 10^{5}$ ).

Peripheral blood nucleated red cells. Six of the nine patients reported in detail here showed an increase in absolute nucleated erythrocyte count in the peripheral blood after treatment with 5-azacytidine as previously described (18) (Table II). The maximal increment occurred on days 7-10 and ranged from 3- to 13-fold. All six patients who showed an increase in this parameter have sickle cell anemia. In contrast, the three patients whose nucleated erythrocyte count decreased or did not change have homozygous $\beta$-thalassemia.

Erythroid progenitors. The next series of experiments was designed to evaluate the effects of 5-azacytidine treatment on primitive and mature erythroid progenitors. Serial bone marrow samples were obtained before, during, and after the course of 5 -azacytidine and cultured in the absence of 5-azacytidine. The data obtained by study of patients treated by continuous infusion (Fig. 4, $A$ and $B$ ) are plotted separately from those 


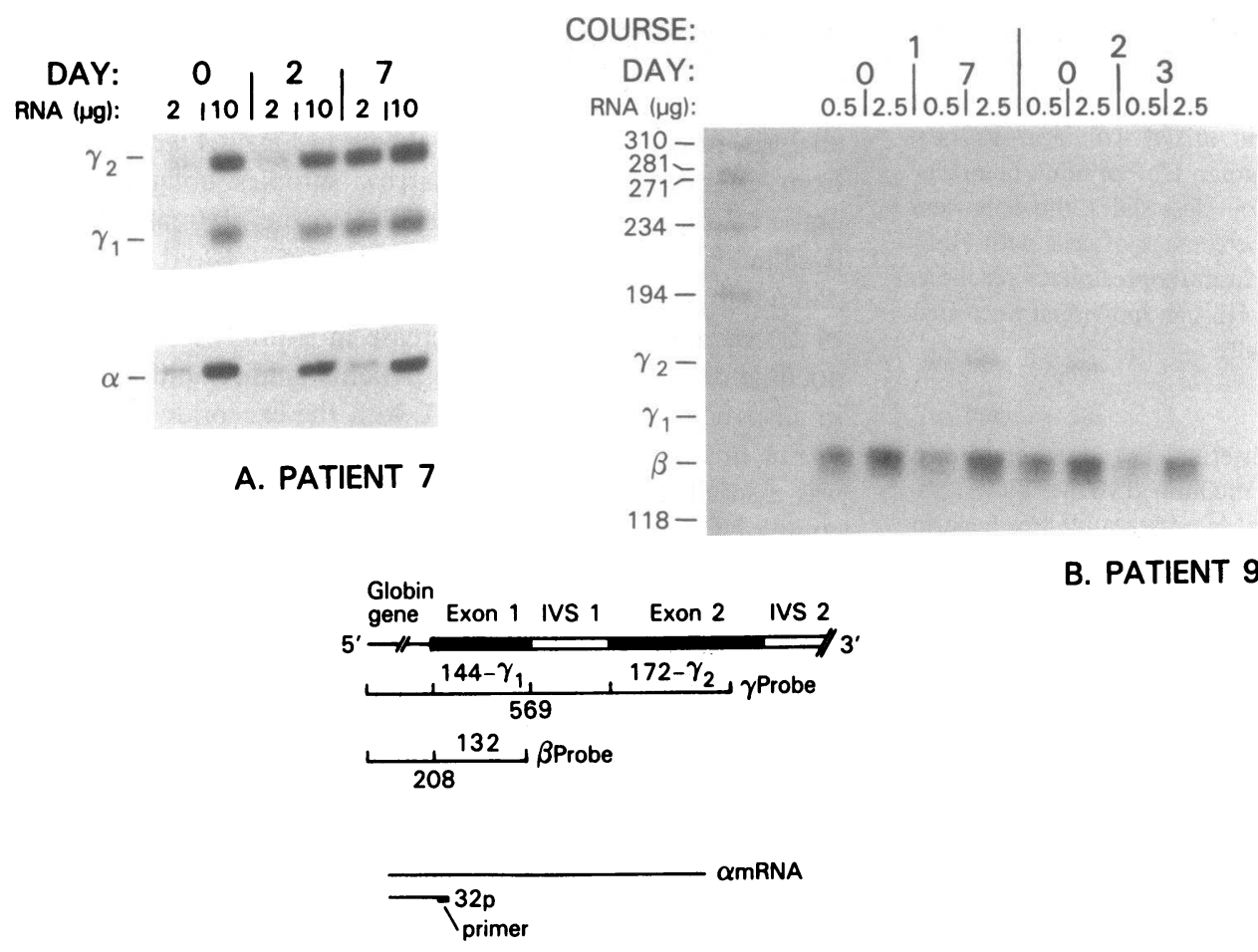

Figure 1. Analysis of $\gamma$-globin mRNA in bone marrow obtained from patients receiving 5-azacytidine. $(A)$ Response of patient 7. $\gamma-$ globin mRNA was assessed by $S_{1}$ nuclease mapping with a uniformly labeled $\gamma$-globin gene-specific probe. As a control, $\alpha$-mRNA was assessed by primer extension by use of an $\alpha$ globin gene-specific probe. The origin of the probes used is described in Methods and is depicted at the bottom of the figure with reference to a prototypical globin gene. The expected fragments protected from $S_{1}$ nuclease digestion or resulting from primer extension are indicated above the lines representing the probes. The numbers below the line indicate the total length of the probe. The day of treatment on which bone marrow was obtained and the amount and total RNA analyzed are shown above each lane. Each RNA sample was analyzed in replicate by hybridization to either the $\gamma$-specific probe or the $\alpha$-specific probe followed by $S_{1}$ nuclease or primer extension, respectively. Radiolabeled products were resolved on separate sequencing gels with subsequent autoradiography. The results obtained for the $\alpha$-specific probe are shown directly below the corresponding lanes of the $\gamma$-specific probe. (B) Response of patient 9. For this patient, total bone marrow RNA was simultaneously assessed for $\gamma$ - and $\beta$-globin mRNA by annealing RNA samples to a mixture of the $\gamma$-specific probe as described in $A$ and a $\beta$-specific probe spanning the $5^{\prime}$ end of the gene as depicted in the lower part of the figure. The day on which the bone marrow was taken and the amount of RNA used in the hybridization are indicated at the top of each lane. After $S_{1}$ nuclease treatment, samples were analyzed on sequencing gels with subsequent autoradiography.

obtained by study of patients who received the bolus infusions (Fig. 4, $C$ and $D$ ). Of the six patients whose marrow was assayed on day 2 of treatment, only one showed a modest decrease of $30 \%$ in CFU-E as compared with the pretreatment value, whereas the remainder showed stable or even increased values (0-65\%). Two additional patients, for whom no data was available from day 2 , were found to have a striking increase in colony numbers in bone marrow samples cultured on day 7. Cytotoxicity to the progenitor compartment (as reflected by a decrease in CFU-E derived colonies) was evident by day 7 or later for five patients. The variablility in colony formation among six normal individuals (each studied 2 or 3 times) expressed as an average standard deviation of the means was 13.3 with a range of $42-162$ CFU-E derived colonies/ $10^{5}$ bone marrow mononuclear cells. Thus, we believe that the changes observed during and after treatment are not due to random variation between samples.

Detailed analyses of $\mathrm{HbF}$ content in erythroblasts derived from erythroid progenitors in vitro were obtained for three patients who showed an increase in CFU-E numbers on either day 2 (patients 7 and 8 ) or day 7 (patient 5) of the treatment course. Well-hemoglobinized colonies derived from mature progenitors were identified and plucked from cultures on the eighth day in vitro and pooled, and the $\mathrm{HbF}$ content of individual erythroblasts was determined by radial immunodiffusion. These data are presented in Fig. 5 as plots of the cumulative frequency of erythroblasts containing different amounts of $\mathrm{HbF}$. By day 2 of treatment, two patients (Fig. 5, $A$ and $B$ ), and by day 7 of treatment, all three patients studied, showed an increase in HbF content in CFU-E derived erythroblasts, as reflected by a shift in the cumulative frequency plot to the right and by an increase in the mean $\mathrm{HbF}$ content per erythroblast. These data show that in vivo exposure of bone marrow to 5 -azacytidine for 2 or $7 \mathrm{~d}$ yields CFU-E progenitors whose phenotype is demonstrably altered; erythroblasts generated in vitro from these progenitors contain increased amounts of $\mathrm{HbF}$ in the absence of further exposure to 5-azacytidine.

In four of the seven patients, the number of colonies derived from BFU-E remained constant or increased during or after the 5-azacytidine treatment course, whereas in three patients a decrease in BFU-E derived colonies was evident in one or more bone marrow samples subsequent to treatment (Fig. 4). One of the two patients (number 7) whose CFU-E derived erythroblasts from day 2 marrow contained increased amounts of $\mathrm{HbF}$ also had an increase in $\mathrm{HbF}$ in BFU-E derived colonies from the day 2 sample (mean day $0,12.94$ pg vs. mean day $2,25.6 \mathrm{pg}$ ). In others the base-line $\mathrm{HbF}$ in BFU-E colonies was high, preventing meaningful analyses.

\section{Manipulation of progenitors with 5-azacytidine in vitro}

The above analyses of erythroid progenitors suggest that short term exposure in vivo to 5-azacytidine altered CFU-E, leading them to form erythroid colonies containing increased amounts of $\mathrm{HbF}$. This alteration occurred in several patients without a decrease in CFU-E numbers or other overt evidence of cytotoxicity. To gain further insight into the mechanisms involved, 
COURSE:

2
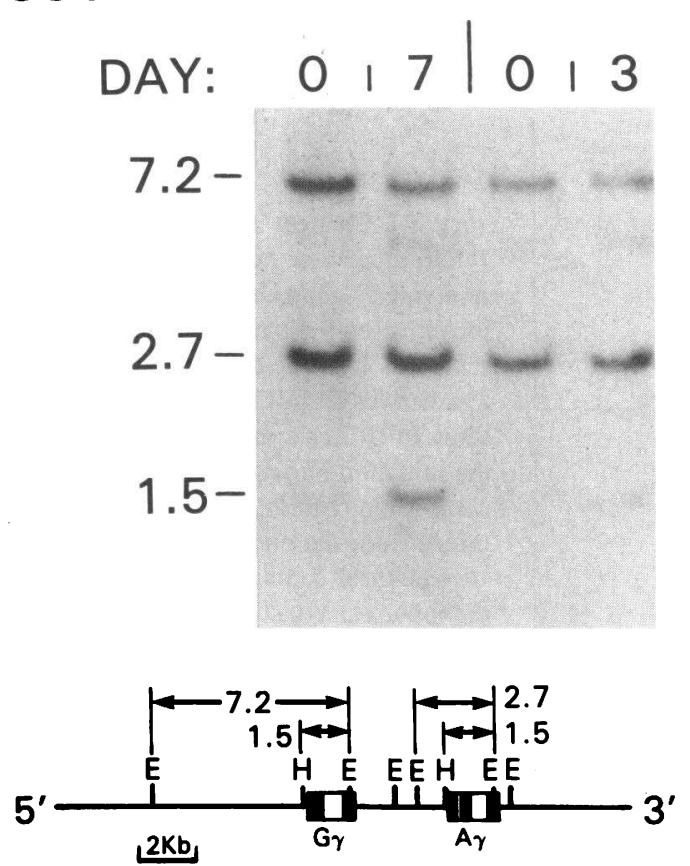

Figure 2. Southern blot analysis of DNA methylation in the region of the human $\gamma$-globin genes for patient 9, treatment courses 1 and 2 . Each lane represents an analysis of total bone marrow DNA (80-90\% erythroid cells) obtained on the indicated day of treatment. Samples were digested to completion with Eco RI and Hpall as described in Methods. Expected fragment sizes are depicted on the schematic of the $\gamma$-globin gene region shown at the bottom of the figure. Flanking sequence DNA is indicated by a line, coding sequences are indicated by black boxes, and intervening sequences are indicated by open boxes. The sizes of fragments expected to hybridize with a nicktranslated $\gamma$-probe derived from the large intervening sequences of the $G_{\gamma}$-gene are indicated. The presence of a $1.5-\mathrm{kb}$ band indicates an absence of cytosine methylation at the Hpall site shown. An additional 5.2-kb band seen in some lanes represents cross hybridization of the probe to a 5.2-kb Eco RI fragment containing the 5 ' end of the human $\beta$-globin gene. No Hpall sites are found within this fragment.

we examined the effects of exposing progenitors to 5-azacytidine in vitro.

Fig. 6 shows the effect on CFU-E derived colony numbers of exposing bone marrow cells from normal volunteers to

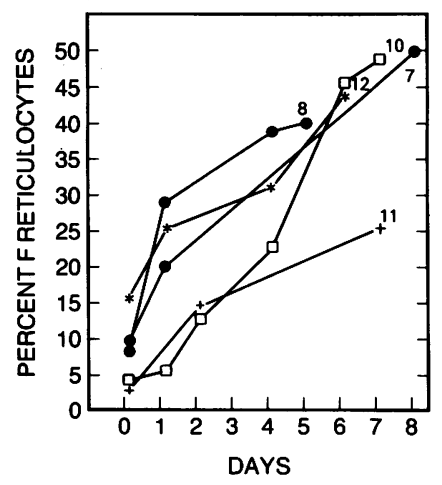

Figure 3. F-reticulocyte response to 5-azacytidine. The percentage of F-reticulocytes in peripheral blood is indicated as a function of days after starting of 5-azacytidine administration. Solid circles with corresponding patient number indicate values from patients with sickle cell anemia treated at the National Institutes of Health (see Table I). The remaining three responses are those for sickle cell anemia patients treated at the Johns Hopkins Hospital.
Table II. Effect of 5-Azacytidine on Nucleated Erythrocyte Counts*

\begin{tabular}{|c|c|c|c|c|}
\hline No. & Patient & Base line & Days 1-5 & Days 7-10 \\
\hline 1 & J.S. & 258 & 0 & $1327(5.1) \ddagger$ \\
\hline 2 & M.G. & 372 & 45 & $1470(4.0)$ \\
\hline 3 & T.A.§ & 502 & 363 & $155(0.3)$ \\
\hline 4 & R.R.§ & 440 & 684 & $437(1.0)$ \\
\hline 5 & C.H.§ & 1230 & 319 & $177(0.14)$ \\
\hline 6 & W.A.J. & 155 & 239 & $1964(12.7)$ \\
\hline 7 & A.L. & 700 & 811 & $1920(2.7)$ \\
\hline 8 & J.I. & 160 & 300 & $2120(13.3)$ \\
\hline \multirow[t]{2}{*}{9} & W.J.J. & 1. 75 & 38 & $704(9.4)$ \\
\hline & & 2. 32 & 50 & $320(10)$ \\
\hline
\end{tabular}

* Values shown are nucleated erythrocytes per cubic millimeter of peripheral blood and were calculated from inspection of peripheral blood smears and reference to total erythrocyte counts. ¥-Fold change days 7-10 as compared with base line.

$\S$ Patients have beta-thalassemia. All others have sickle cell anemia.

different 5-azacytidine concentrations in liquid culture for 24 h. After liquid culture the cells were washed and plated in methylcellulose in the absence of 5-azacytidine and CFU-E derived colonies scored. Significant reductions in colony numbers were not observed until 5-azacytidine concentrations above $1.0 \mu \mathrm{g} / \mathrm{ml}$ were used. At low concentrations an increase in colony number was apparent. The number of BFU-E derived colonies remained constant until $10 \mu \mathrm{g} / \mathrm{ml}$ (data not shown).

Based on these results, bone marrow cells from two normal volunteers were exposed to nontoxic concentrations of 5azacytidine for $24 \mathrm{~h}$ before plating in methylcellulose culture in the absence of 5-azacytidine was done. In colonies derived from the CFU-E of both individuals, there was an increase in the percentage of $\mathrm{HbF}$ containing erythroblasts at doses of 5azacytidine that did not significantly reduce colony number (Table III). At higher concentrations a statistically significant increase in $\mathrm{HbF}$ per erythroblast was also observed for the colonies derived from bone marrow cells of both individuals, although in one case (experiment 2) this was accompanied by a substantial reduction in colony number (Table III).

\section{Correlation of the effect of 5-azacytidine on erythropoiesis} with the clinical response in individual patients

Good responders. 5-Azacytidine caused a progressive increase in $\mathrm{HbF}$ concentration and an increase in the total hemoglobin concentration in several patients. Such a response has previously been described in patients $1-5(13,14)$; the clinical course of two additional patients ( 8 and 7 ) is shown in Fig. 7. These two patients who have sickle cell anemia had a prompt increase in the absolute F-reticulocyte count, an increase in the nucleated erythrocyte count, and a documented increase in mRNA content in bone marrow erythroblasts during and after 5azacytidine administration. The concentration of bone marrow erythroid progenitors that formed colonies remained stable (e.g., patient 8, Fig. 7) or increased (e.g., patient 7, Fig. 7) by day 2 of treatment and there was a documented increase in $\mathrm{HbF}$ in these colonies as compared with control colonies (Fig. 5).

Certain patients who exhibit the clinical response described above nonetheless show a decrease in colony numbers by day 


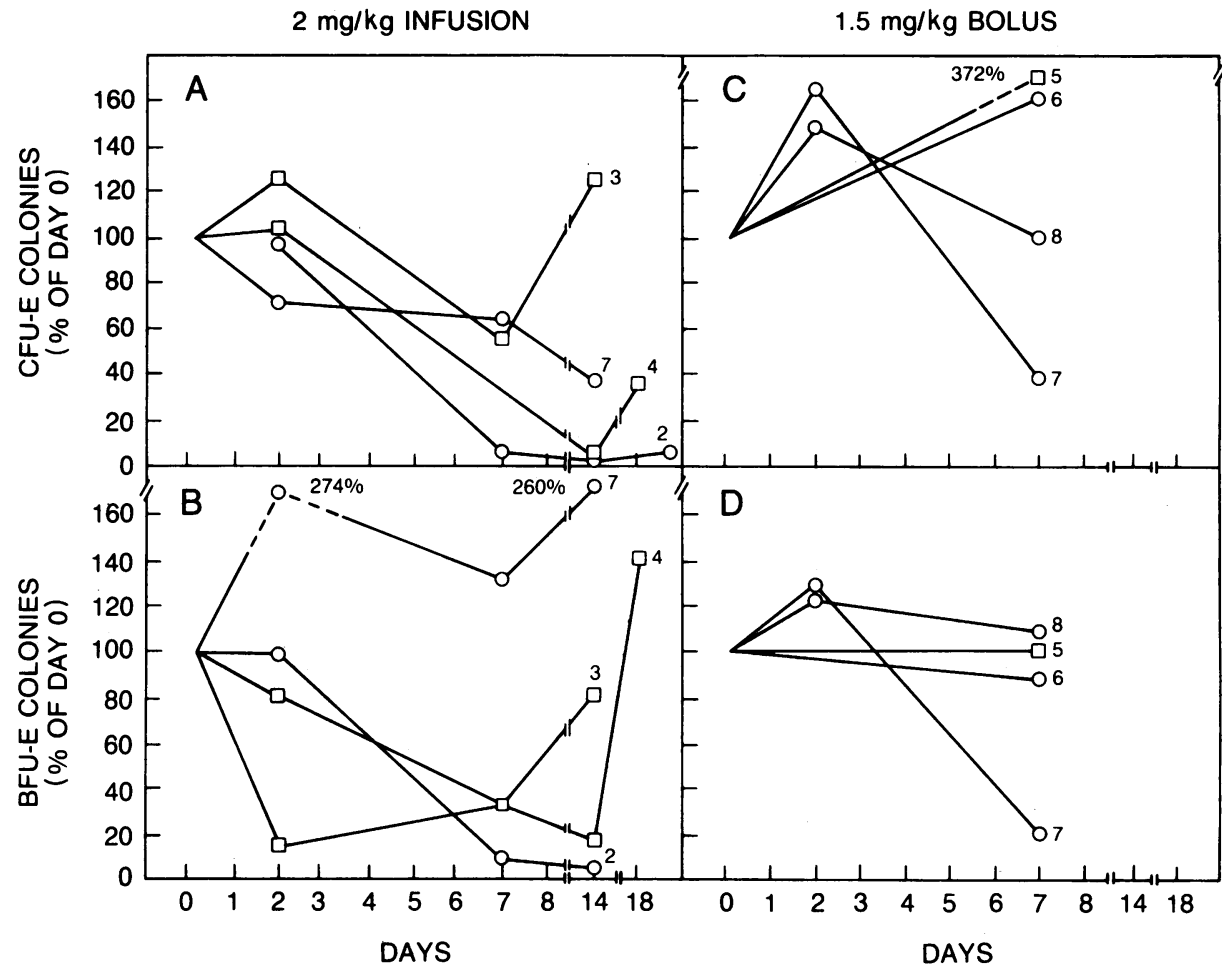

Figure 4. Changes in bone marrow erythroid progenitor number in patients receiving 5-azacytidine. Responses are identified by the patient number as presented in Table I, $A$ and $C$ depict colonies derived from CFU-E and $B$ and $D$ show BFU-E as a function of time after the initiation of 5-azacytidine treatment. Colony numbers were determined from the mean value in replicate 1 -ml cultures containing $1 \times 10^{5}$ mononuclear bone marrow cells; values are expressed as a percentage of the pretreatment level (day 0). The data in $A$ and $B$ were derived from study of patients who received $7 \mathrm{~d}$ of continuous infusion (regimen A); data in $C$ and $D$ were derived from study of patients who received a daily $8-h$ infusion for 5 d (regimen B).
7 (patients 2 and 7). In one case this decrease in colony numbers was found to correlate with a fall in reticulocyte count as described for patient 2 previously. Relevant data are not available for patient 7 .

Moderate responders. Patient 6 represents a different pattern of response. This patient exhibited a striking increase in absolute F-reticulocytes that was accompanied by a progressive rise in the $\mathrm{HbF}$ concentration in blood to approximately six times higher than the pretreatment level but not by a rise in total hemoglobin (Fig. 8). The increase in $\mathrm{HbF}$ concentration in blood between days 5 and 15 did not result in a significant increase in total hemoglobin concentration. Apparently the magnitude of the increase in $\mathrm{HbF}$ was compromised by a rebound absolute reticulocytosis and a fall in the absolute $F$ reticulocyte count between days 9 and 14. These in vivo results correlated with the in vitro culture data. As compared with the day 0 sample, the number of mature progenitors (CFU-E) that formed colonies had increased twofold in the day 7 sample, consistent with rebound absolute reticulocytosis. The erythroblasts derived from these progenitors in vitro showed no increase in HbF content as compared with control (Fig. 9).

Nonresponder. Finally, one patient (number 9) had no significant increase in $\mathrm{HbF}$ concentration after treatment; this patient's hemoglobin concentration fell after treatment regimen B (Fig. 10). He was treated a second time with regimen A, which was previously found to be effective in patients 1-5. Serial measurement of F-reticulocytes were made and the behavior of progenitors before and after initiation of 5-azacytidine was determined. Only a very modest increase in $\mathrm{HbF}$ concentration was found in peripheral blood; this increase occurred several days after the treatment course was completed (Fig. 10). Toxicity to the bone marrow was reflected by a striking fall in absolute reticulocyte count. The absolute Freticulocyte count remained relatively constant, however, re- sulting in a moderate increase in the percentage of F-reticulocytes. Accordingly, this period of relative reticulocytopenia but relative increase in F-reticulocytes was followed by a modest increase in $\mathrm{HbF}$ concentration. Restoration of reticulocyte numbers to near base-line values between days 23 and 27 was not accompanied by an increase in the number of F-reticulocytes. Consistent with these findings, the $\mathrm{HbF}$ content of erythroblasts present in CFU-E derived colonies were identical in cultures of bone marrow obtained on day 0 and day 3 ; thus his progenitor cells were apparently not altered upon exposure to 5-azacytidine in vivo (Fig. $9 \mathrm{~B}$ ).

Of interest in this nonresponder, the base-line $\mathrm{HbF}$ content per erythroblast in his colonies was higher than that found in the colony erythroblasts of any other patient. Even though there was no clinical or in vitro evidence of an increase in $\mathrm{HbF}$ synthesis, a decrease in the frequency of methylation in the region of the $\gamma$-globin genes was documented during both treatment periods (Fig. 2).

\section{Discussion}

Our studies have documented the time course of the effect of 5 -azacytidine on the erythroid precursor and progenitor cell compartments. A direct effect on the erythroid precursor compartment is suggested by an early rise in F-reticulocytes and by an early increase in bone marrow cell $\gamma$-mRNA content. The earliest effect of 5-azacytidine on the progenitor compartment is an increase in the amount of $\mathrm{HbF}$ in the CFU-E without overt cytotoxicity to this compartment as compared with control colonies. Finally, we have found considerable heterogeneity in the clinical response to 5-azacytidine as reflected by $\mathrm{HbF}$ and hemoglobin eoncentrations. In general there was a correlation between the in vitro measurements of the effect of 5-azacytidine on progenitors and precursors and the clinical response of individual patients. 

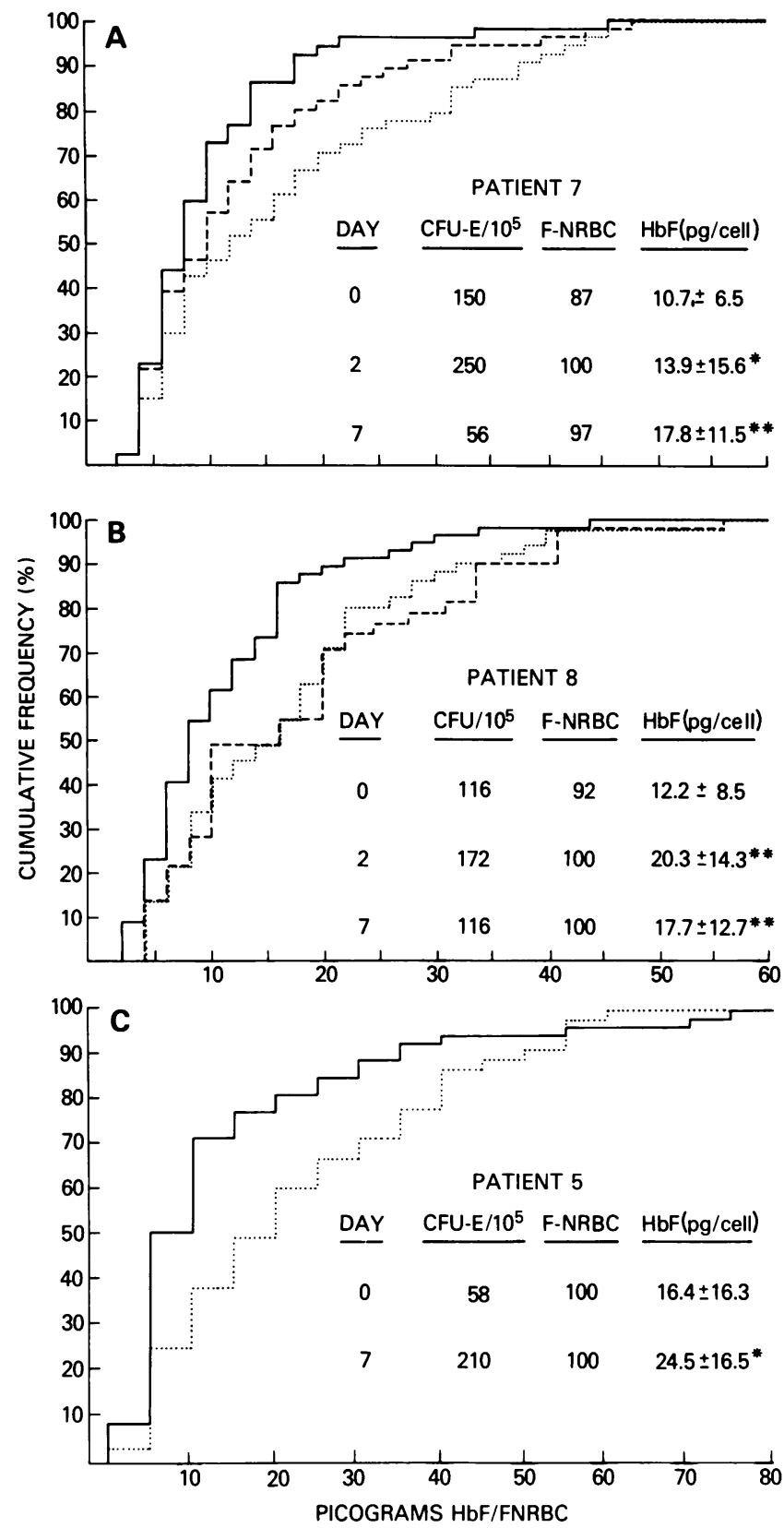

Figure 5. HbF content of nucleated erythrocytes generated in vitro by CFU-E from patients treated with 5-azacytidine. Well-hemoglobinized colonies derived from CFU-E were identified and plucked from cultures of bone marrow cells on the eighth day in vitro; colonies were pooled and resuspended, and $\mathrm{HbF}$ content of individual erythroblasts was determined by radioimmunodiffusion. Data are presented as a cumulative frequency plot of cells containing up to a given amount of $\mathrm{HbF}$. Note that colony erythroblasts contain 40-60 pg of total hemoglobin. $A, B$, and $C$ depict response of patients 7,8 , and 5, respectively (see Table I). Responses are shown for bone marrow taken before initiation of 5-azacytidine administration (day $0,-$ ) and at day $2(---)$ and/or day $7(\cdots)$ after the initiation of therapy. F-NRBC, percentage of nucleated erythrocytes that contain $\mathrm{HbF} .{ }^{*}, P<0.05$. ${ }^{* *}, P<0.01$.

The careful study of Torrealba-de Ron et al. (19) revealed toxic effects of 5-azacytidine on erythroid progenitors of baboons (Papio cynocephalus) during the induction of $\mathrm{HbF}$ synthesis. $5 \mathrm{~d}$ of drug treatment were given at a dose of $5 \mathrm{mg} / \mathrm{kg} ; 1 \mathrm{~d}$

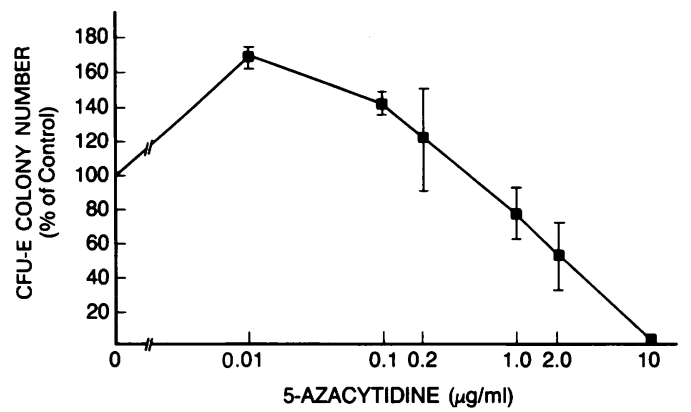

Figure 6. Toxicity profile for CFU-E after exposure to 5-azacytidine in vitro. Bone marrow cells from normal volunteers were placed in liquid culture containing 5-azacytidine at concentrations ranging from 0.1 to $10 \mu \mathrm{g} / \mathrm{ml}$ as described in Methods. Five separate experiments were performed. To maintain the specified concentrations, additional 5-azacytidine was added 8 and $16 \mathrm{~h}$ after initiation of incubation (this drug is very unstable after reconstitution). After 24 $h$, cells were washed and replated in methylcellulose at $1 \times 10^{5}$ cells/ $\mathrm{ml}$ in the absence of 5-azacytidine. CFU-E derived colonies were scored $8 \mathrm{~d}$ later. Results from individual experiments were expressed as a percentage of values obtained in the absence of 5-azacytidine, and the mean and standard error of the mean, obtained upon pooling results from three to five experiments per point were plotted.

later (corresponding to day 6 of our treatment schedules) the numbers of erythroid colonies (derived from CFU-E) and erythroid clusters (derived from pro-erythroblasts) were significantly reduced as compared with pretreatment values. The number of burst colonies was unaffected by 5 -azacytidine treatment. $6 \mathrm{~d}$ later (corresponding to day 12 of our treatment schedules) the number of clusters and colonies that formed in bone marrow cultures was increased over those observed in

Table III. Effect of 5-Azacytidine on Normal Marrow Progenitors In Vitro*

\begin{tabular}{lcll}
\hline 5-Aza & CFU-E & \%FNRBC & HbF/FNRBC \\
\hline$\mu g / m l$ & $\times 10^{5}$ cells & & $p g$ \\
Experiment 1 & & & \\
$\quad 0$ & 92 & $24.4 \pm 3.2$ & $5.0 \pm 2.2$ \\
0.2 & 140 & $38.8 \pm 2.3 \ddagger$ & $5.8 \pm 2.1$ \\
1.0 & 74 & $36.8 \pm 1.4 \ddagger$ & $11.3 \pm 10.1 \ddagger$ \\
Experiment 2 & & & \\
0 & 46 & $61.3 \pm 4.6$ & $6.6 \pm 3.3$ \\
0.05 & 56 & $59.3 \pm 2.3$ & $9.0 \pm 7.0$ \\
0.2 & 72 & $68.0 \pm 2.0 \S$ & $8.4 \pm 9.6$ \\
1.0 & 17 & $83.3 \pm 1.2 \ddagger$ & $9.8 \pm 6.3 \ddagger$
\end{tabular}

* Bone marrow mononuclear cells from two normal adults (experiments 1 and 2) were incubated in liquid culture in vitro with 5-azacytidine (5-Aza), and then washed and plated in methylcellulose culture without 5-azacytidine. CFU-E derived colonies were counted and $\mathrm{HbF}$ analyzed in cells from pools of plucked colonies by the radial immunodiffusion assay. Values shown are means \pm SD. For determination of percentage of nucleated erythroblasts containing $\mathrm{HbF}$ (FNRBC), 250 cells were counted; the HbF/FNRBC was determined for $50-100$ cells.

$\ddagger P=0.01$.

$\S P=0.05$ 


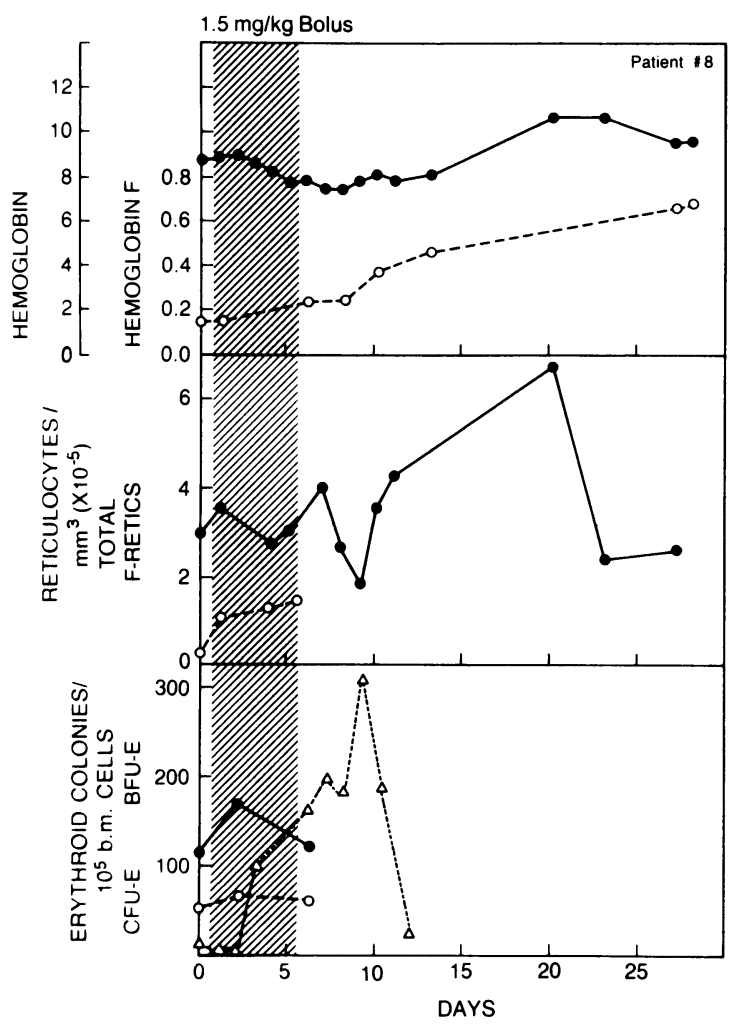

base-line studies. No cultures corresponding to our day 2 studies were obtained during 5-azacytidine administration. Torrealba-de Ron et al. (19) suggested that these toxic effects on late erythroid progenitors and the subsequent regeneration

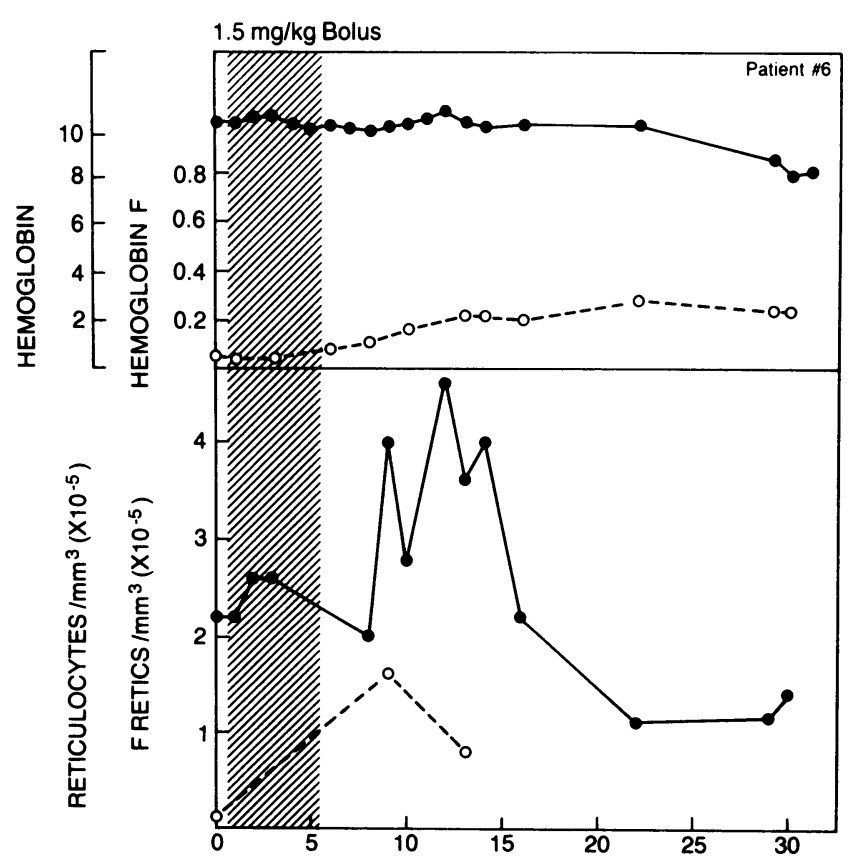

Figure 8. Clinical course of a moderate responder (patient 6) to treatment with 5 -azacytidine. Shown are the total $(g / d l,-\bullet-)$ and

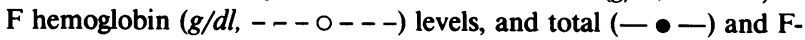
reticulocyte (- - $\left.\mathrm{O}_{---}\right)$counts during (shaded area) and after administration of 5 -azacytidine.

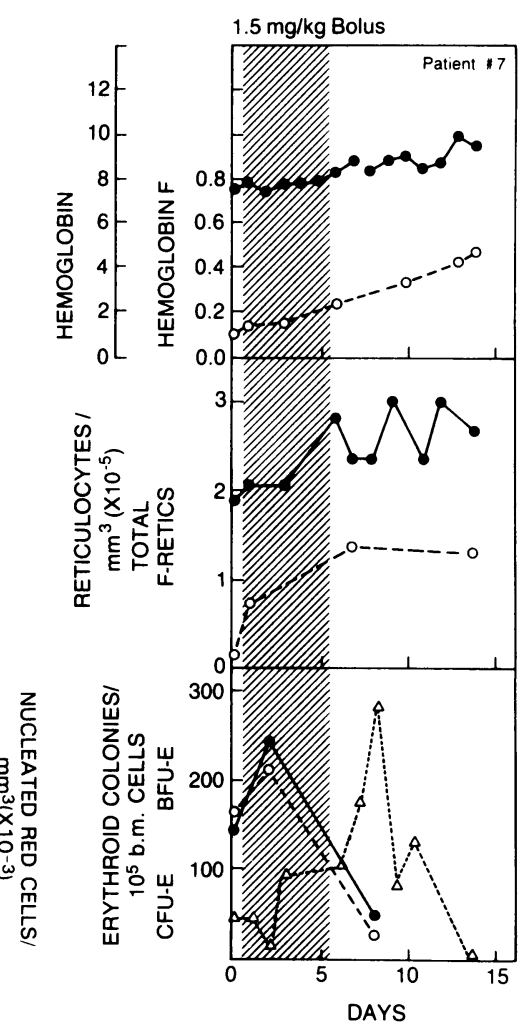

Figure 7. Clinical courses of patients 8 (left) and 7 (right) on treatment with 5-azacytidine. The periods of 5-azacytidine administration are shaded. The hemoglobin $(g /$ $d l,-\bullet-)$ and hemoglobin F level $(g / d l,---0---)$, total (-๑-), and F-reticulocyte (- - - ---$)$ counts, nucleated erythrocytes $(---\Delta---)$, and erythroid colonies per $10^{5}$ bone marrow cells (CFU-E, - - and BFU-E, - - - O-- -) are plotted for the patient indicated.

of these late progenitors from earlier progenitors were responsible, at least in part, for the augmentation in synthesis of $\mathrm{HbF}$. A shift to a less mature progenitor as a source of erythroblasts and ultimately reticulocytes has also been proposed as the basis for the ability of hydroxyurea to augment $\mathrm{HbF}$ synthesis in anemic monkeys (Macaca fascicularis) (20).

We interpret our analysis of the kinetics of the effect of 5azacytidine on human erythroid cells as being most consistent with a direct action of 5-azacytidine on erythroblasts; moreover, a toxic or cytoreductive action on late progenitors is not necessary to achieve an increase in $\mathrm{HbF}$ synthesis in the erythroblasts derived from these cells. Strongly supporting a direct action are the early rise in F-reticulocytes and $\gamma$-mRNA levels reported herein and in previous studies (16-18). For example, patients 7 and 8 exhibited a two to threefold increase in the percentage of F-reticulocytes within 24-48 h of starting 5-azacytidine treatment (Fig. 4) without a significant change in total reticulocyte concentration. Ferrokinetic studies (33) and ${ }^{59} \mathrm{Fe}$-labeling of bone marrow cells (34) suggest a transit time from bone marrow proerythroblasts to peripheral blood reticulocytes of from 72 to $95 \mathrm{~h}$. Although this interval might be shortened in the presence of hemolysis, accelerated erythropoiesis, and drug administration, it seems unlikely that reticulocyte counts could be sustained at relatively constant levels during 5-azacytidine administration by recruitment and accelerated maturation of erythroid progenitors if there were substantial killing of cells already in the erythroblast compartment. The mechanism of this early effect on the erythroblast population remains conjectural but presumably must depend on some distortion of the normal erythroid maturational kinetics.

$48 \mathrm{~h}$ after treatment is started, hypomethylation of a $\mathrm{CpG}$ residue immediately upstream from the $\gamma$-gene coding se- 


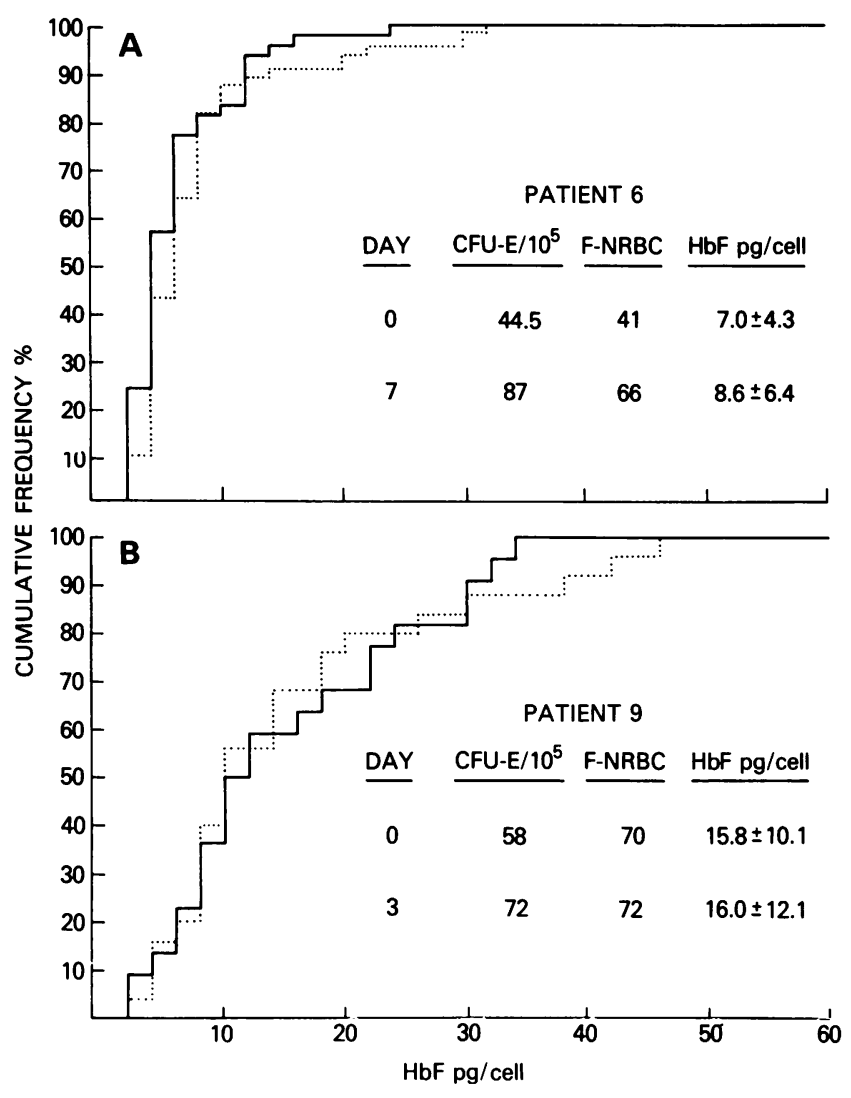

Figure 9. $\mathrm{HbF}$ content of individual nucleated erythrocytes derived in vitro from CFU-E obtained from two patients who received 5azacytidine. Well-hemoglobinized colonies derived from CFU-E were plucked on the eighth day of in vitro culture and $\mathrm{HbF}$ content of individual erythroblasts was determined by radial immunodiffusion. Note that colony erythroblasts contain $40-60 \mathrm{pg}$ of total hemoglobin. $A$ depicts the results from patient 6 (see Table $\mathrm{I}$ ) and $B$ depicts the results from patient 9 during his second treatment course (see Table I). Data are presented as cumulative frequency plots of erythroblasts containing up to a certain amount of $\mathrm{HbF}$. Determinations were made on bone marrow samples obtained at the start of 5-azacytidine treatment (day $0, \longrightarrow$ ) and 3 or $7 \mathrm{~d}$ later $(\cdots \cdots)$. quences is demonstrable in the bone marrow cells of most patients (35). However, the causal role of demethylation in inducing gene expression has been questioned $(36,37)$. Indeed, the ability of 5 -azacytidine to specifically turn on the $\gamma$-gene but not other genes is not readily explained, although it may be argued that hypomethylation is necessary but insufficient for gene activation. Indeed, failure of patient 9 to show an increase in $\mathrm{HbF}$ synthesis despite demonstrated hypomethylation of $\gamma$ gene sequences supports this interpretation. Recently, activation of the $\gamma$-globin gene but not the genes for $\epsilon$-globin or insulin, has been shown to occur after treatment of somatic hybrid cells with 5-azacytidine in vitro (38). These hybrid cells, derived by fusion of mouse erythroleukemia cells and human fibroblasts containing a chromosome X-11 translocation, usually express only the human $\beta$-globin gene after induction to erythroid maturation. The selective activation of the $\gamma$-gene in these cells by 5-azacytidine, despite generalized DNA hypomethylation, indicates that this restricted effect on the $\gamma$-gene can occur outside of the normal pathway of erythroid progenitor and precursor maturation.

An alternative mechanism by which 5-azacytidine could enhance globin production in erythroblasts relates to the known asynchronous synthesis of $\mathrm{HbF}$ and $\mathrm{HbA}$ during erythroid maturation (2-4). HbF synthesis apparently occurs mainly in pro- and basophilic erythroblasts; $\mathrm{HbA}$ synthesis begins slightly later in the maturation pathway but greatly exceeds $\mathrm{HbF}$ synthesis during the later stages of erythroblast maturation. Cell-cycle specific agents such as 5-azacytidine might alter the kinetics of cell division and delay the normal switch from $\mathrm{HbF}$ to $\mathrm{HbA}$ during cellular maturation in the erythroblast compartment. To account for the increased percentage of F-reticulocytes by this mechanism would require that drug administration also increase the proportion of erythroblasts that make $\mathrm{HbF}$.

Erythroid progenitors exposed to 5-azacytidine either in vivo or in vitro yielded colonies that made more $\mathrm{HbF}$ than did control progenitors, even though colony formation occurred in the absence of the drug. Moreover, the number of progenitors detected was stable or even increased after short exposure to

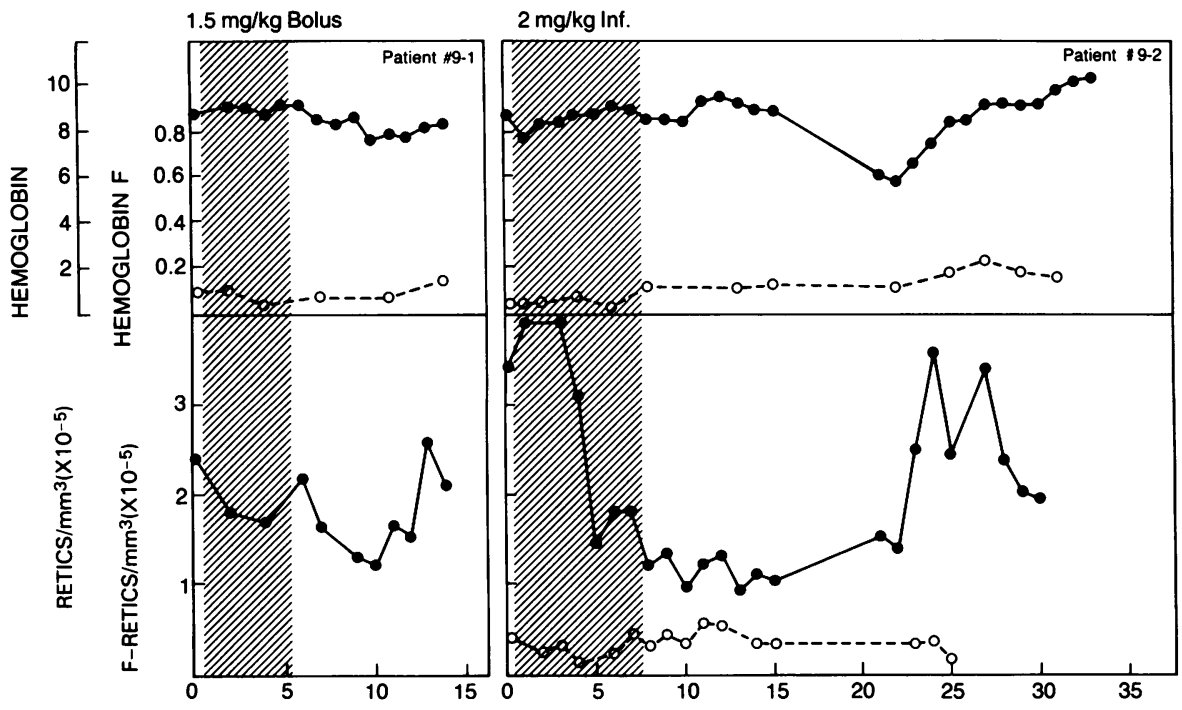

Figure 10. Clinical course of a nonresponder (patient 9) during two courses of 5 -azacytidine treatment. Shown are total hemoglobin $(g / d l,-\bullet-)$ and $\mathrm{HgF}$ $(---0---)$ levels, and total $(-\bullet-)$ and F-reticulocytes (-- - $0---)$ over the course of two 5-azacytidine treatment regimens (see Table I). The period of administration of 5-azacytidine is indicated by the shaded area. 
5-azacytidine. Taking these results together we argue that the initial effect of 5-azacytidine on the erythroid progenitor compartment observed after $2 \mathrm{~d}$ of drug administration and the subsequent increase in HbF synthesis do not occur by significant cytoreduction and then regeneration of erythroid progenitors. Rather, 5-azacytidine leads to progenitors committed to increased $\mathrm{HbF}$ production.

The possible mechanisms for this early effect on erythroid colony-forming cells are (a) reprogramming of individual erythroid progenitors, perhaps by a demethylating effect, or (b) recruitment of erythroid progenitors that normally would not contribute to the pool of maturing erythroid precursors. We cannot exclude the possibility of a rapid cytotoxic action with a rapid recovery in vivo since time points for bone marrow sampling were necessarily limited. Definitive tests of these possibilities await the availability of purified populations of erythroid progenitors where reprogramming, recruitment, and cytotoxicity can be rigorously assessed. We observed variable toxicity on the late erythroid progenitor cells in cultures of bone marrow obtained on day 7 of the treatment schedule analogous to the decrease in colony forming progenitors in bone marrows from baboons on day 6 of their treatment schedule with 5-azacytidine (19). Evidence of cytotoxicity should not be used to infer that this is necessarily the mechanism by which the drug works. Our data seem most consistent with the interpretation that this late toxic effect is neither crucial for, nor consistent with, the kinetics of the observed increase in $\mathrm{HbF}$ synthesis. The direct demethylating effect of 5-azacytidine is not required since hydroxyurea (20) and arabinosylcytosine (39) also lead to increased HbF synthesis. The data seem most consistent with a recruitment model analogous to that proposed by Papayannopoulou et al. (39) although we disagree with their interpretation that significant cytoreduction is required.

The previously reported (18) increase in nucleated erythrocytes in the peripheral blood of sickle cell anemia patients between 6 and $10 \mathrm{~d}$ after treatment with 5-azacytidine is initiated has proven to be a consistent effect, although it does not occur in patients with thalassemia. We understand neither the mechanism of this effect nor the reason why it is restricted to those patients with sickle cell anemia. The increase in nucleated erythrocyte count follows the increase in assayable erythroid progenitors by 4-8 d. Perhaps the properties of erythroid precursors derived from the early recruited progenitors are altered in a way that allows their accelerated release from the bone marrow.

Our experience has revealed considerable heterogeneity in the clinical response to 5-azacytidine. Many patients show an early rise in F-reticulocytes and a sustained increased in $\boldsymbol{\gamma}$ globin gene expression, leading to a progressive five to sixfold increase in $\mathrm{HbF}$ and a steady rise in hemoglobin concentration (Fig. 7). Other patients show only a moderate increase in gene expression and $\mathrm{HbF}$ concentration but little or no increase in hemoglobin concentration (Fig. 8). In a minority of patients with sickle cell anemia, $\mathrm{HbF}$ containing erythrocytes do not appear to have prolonged survival as compared with non-HbF containing cells (40), which perhaps accounts for the failure of the hemoglobin concentration to rise in some patients treated with 5-azacytidine.

One of the nine patients showed no significant increase in $\gamma$-gene expression, as assessed by enumeration of F-reticulocytes or measurement of $\gamma$-mRNA concentration in bone marrow.
Selective toxicity to those cells producing only $\mathrm{HbA}$ resulted in a substantial fall in total reticulocytes but a constant Freticulocyte concentration led to a modest increase in $\mathrm{HbF}$ concentration in blood. The kinetics of this response were quite different from those of the response exhibited by patients who have a substantial increase in $\gamma$-gene expression as judged by the F-reticulocyte increment and an increase in $\boldsymbol{\gamma}$-mRNA concentration in bone marrow (compare Fig. 7 with Fig. 10).

5-Azacytidine appeared to hold some promise for the treatment of patients with sickle cell disease. Charache and Dover have treated three patients for extended periods and observed a persistent increase in $\mathrm{HbF}$ concentration and some clinical improvement (21). A controlled trial could now be justified and would be required to determine whether significant clinical benefit could be achieved with the drug. For the present, however, use of 5-azacytidine in humans has been discontinued. This decision is based on concern about its potential carcinogenic effect and because cytosine arabinoside (39) and hydroxyurea (20) have also been shown to increase HbF synthesis. These drugs, particularly hydroxyurea, are thought to be less carcinogenic. That low doses of 5-azacytidine increase $\mathrm{HbF}$ synthesis without depressing the bone marrow may have important implications for the choice of dose and schedule of administration of other drugs, given in an effort to achieve a clinically useful increase in production of $\mathrm{HbF}$.

\section{Acknowledgments}

We thank Pat Turner for her excellent technical assistance and Lynn Baker for her skill in preparation of the manuscript.

Dr. Charache (HL-02799) and Dr. Dover (HLAM-28022 and RCDA-1K0400689) are grateful to the National Institutes of Health for grant support.

\section{References}

1. Boyer, S. H., T. K. Belding, A. Noyes, and L. Margolet. 1975. Fetal hemoglobin restriction to a few erythrocytes (F-cells) in normal human adults. Science (Wash. DC). 188:361-364.

2. Dover, G. J., and S. H. Boyer. 1980. Quantitation of hemoglobins within individual red cells: asynchronous biosynthesis of fetal and adult hemoglobin during erythroid maturation in normal subjects. Blood. 56:1082-1091.

3. Wood, W. G., and R. W. Jones. 1981. Erythropoiesis and hemoglobin production: a unifying model involving sequential gene activation. In Hemoglobins and Development in Differentiation. G. Stamatoyannopoulos and A. W. Nienhuis, editors. Alan R. Liss, Inc., New York. 243-261.

4. Papayannopoulou, Th., T. Kalmantis, and G. Stamatoyannopoulos. 1979. Cellular regulation of hemoglobin switching: evidence for inverse relationship between fetal hemoglobin synthesis and degree of maturity of human erythroid cells. Proc: Natl. Acad. Sci. USA. 76: 6420-6424.

5. Papayannopoulou, Th., M. Brice, and G. Stamatoyannopoulos. 1976. Stimulation of fetal hemoglobin synthesis in bone marrow cultures from adult individuals. Proc. Natl. Acad. Sci. USA. 73:20332037.

6. Papayannopoulou, Th., M. Brice, and G. Stamatoyannopoulos. 1977. Hemoglobin F synthesis in vitro: evidence for control at the level of primitive erythroid stem cells. Proc. Natl. Acad. Sci. USA. 74:2923-2927.

7. Dover, G., and M. Ogawa. 1980. Cellular mechanisms for increased fetal hemoglobin production in culture. J. Clin. Invest. 66:1175-1178.

8. Kidoguchi, K., M. Ogawa, and J. D. Karam. 1979. Hemoglobin biosynthesis in individual erythropoietic bursts in culture. J. Clin. Invest. 63:804-806. 
9. Weinberg, R. S., S. D. Goldberg, and B. P. Alter. 1981. Asynchrony of $\gamma / \beta$ and $G_{\gamma}$ synthesis in newborn and adult erythroid cultures. Blood. 58:68a. (Abstr.)

10. Alter, B. P. 1979. Fetal erythropoiesis in bone marrow failure syndromes. In Cellular and Molecular Regulation of Hemoglobin Switching. G. Stamatoyannopoulos and A. W. Nienhuis, editors. Grune \& Stratton Inc., New York. 87-105.

11. Dover, G. J., S. H. Boyer, and W. H. Zinkham. 1979. Production of erythrocytes that contain fetal hemoglobin in anemia. Transient in vivo changes. J. Clin. Invest. 62:173-176.

12. Stamatoyannopoulos, G., and A. W. Nienhuis. 1981. Organization and Expression of Globin Genes. Alan R. Liss, Inc., New York. 337 pp.

13. Groudine, M., T. Kohwi-Shigematsu, R. Gelinas, G. Stamatoyannopoulos, and Th. Papayannopoulou. 1983. Human fetal to adult hemoglobin switching: changes in chromatin structure of the beta globin gene locus. Proc. Natl. Acad. Sci. USA. 80:7551-7555.

14. Van der Ploeg, L. H. T., and R. A. Flavell. 1980. DNA methylation in human $\beta$-locus in erythroid and nonerythroid tissues. Cell. 19:947-958.

15. DeSimone, J., P. Heller, L. Hall, and D. Zwiers. 1982. 5Azacytidine stimulates fetal hemoglobin $(\mathrm{HbF})$ synthesis in anemic baboons. Proc. Natl. Acad. Sci. USA. 79:4428-4431.

16. Ley, T. J., J. DeSimone, N. P. Anagnou, G. H. Keller, R. K. Humphries, P. H. Turner, N. S. Young, P. Heller, and A. W. Nienhuis. 1982. 5-Azacytidine selectively increases $\gamma$-globin synthesis in a patient with $\beta^{+}$thalassemia. N. Engl. J. Med. 307:1469-1475.

17. Ley, T. J., J. Desimone, C. T. Noguchiu, P. H. Turner, A. N. Schechter, P. Heller, and A. W. Nienhuis. 1983. 5-Azacytidine increases $\boldsymbol{\gamma}$-globin synthesis and reduces the proportion of dense cells in patients with sickle cell anemia. Blood. 62:370-380.

18. Charache, S., G. Dover, K. Smith, C. C. Talbot, M. Moyer, and S. Boyer. 1983. Treatment of sickle cell anemia with 5-azacytidine results in increased fetal hemoglobin production and is associated with non-random hypomethylation of DNA around the $\beta$-globin gene complex. Proc. Natl. Acad. Sci. USA. 80:4842-4846.

19. Torrealba-de Ron, A. T., Th. Papayannopoulou, M. S. Knapp, M. Feng-Ruen Fu, G. Knitter, and G. Stamatoyannopoulos. 1984. Perturbations in erythroid marrow progenitor cell pools may play a role in the augmentation of $\mathrm{HbF}$ by 5-azacytidine. Blood. 63:201-210.

20. Letvin, N. L., D. G. Linch, G. P. Beardsley, K. W. McIntyre, and D. G. Nathan. 1984. Augmentation of fetal-hemoglobin production in anemic monkeys by hydroxyurea. N. Engl. J. Med. 310:869-874.

21. Dover, G., S. Charache, and G. Vogelsang. 1983. 5-Azacytidine increases $\mathrm{HbF}$ production in sickle cell anemia: results of 300 days of therapy. Blood. 62:55a. (Abstr.)

22. Kantor, J. A., P. Turner, and A. W. Nienhuis. 1980. $\beta$ Thalassemia: mutations which affect processing of the $\beta$-globin mRNA precursor. Cell. 21:149-157.

23. Favaloro, J. M., R. H. Triesman, and R. Kamen. 1980. Transcription maps of polyoma virus-specific RNAs. Meth. Enzymol. 65:718-749.

24. Treisman, R., N. J. Proudfoot, M. Shander, and T. Maniatis. 1982. A single-base change at a splice site in a $\beta^{0}$ thalassemia gene causes abnormal RNA splicing. Cell. 29:903-911.
25. Ley, T. J., N. P. Anagnou, G. Pepe, and A. W. Nienhuis. 1982. RNA processing in patients with $\beta$-thalassemia. Proc. Natl. Acad. Sci. USA. 79:4775-4779.

26. Maxam, A. M., and W. Gilbert. 1980. Sequencing end-labeled DNA with base-specific chemical cleavages. Meth. Enzymol. 65:499560 .

27. Maniatis, T., E. F. Fritsch, and J. Sambrook. 1982. Molecular Cloning: A Laboratory Manual. Cold Spring Harbor Laboratory, New York.

28. Southern, E. M. 1975. Detection of specific sequences among DNA fragments separated by gel electrophoresis. J. Mol. Biol. 98:503517.

29. Jeffreys, A. J., and R. A. Flavell. 1977. The rabbit $\beta$-globin gene contains a large insert in the coding sequence. Cell. 12:10971108.

30. Singer, K., A. I. Chernoff, and L. Singer. 1951. Studies on abnormal hemoglobin II: their identification by means of the method of fractional denaturation. Blood. 6:428-438.

31. Dover, G., S. H. Boyer, and W. R. Bell. 1978. Microscopic methods for assaying F-cell production: illustrative changes during infancy and aplastic anemia. Blood. 52:664-672.

32. Gregory, C. J., and A. C. Eaves. 1977. Human marrow cells capable of erythropoietic differentiation: Definition of three erythroid colony responses. Blood. 49:855-864.

33. Finch, C. A., K. Deubelbeiss, J. D. Cook, J. W. Eschbach, L. A. Harker, D. D. Funk, G. Marsaglia, R. S. Hillman, S. Slichter, J. W. Adamson, A. Ganzoni, and E. R. Giblett. 1970. Ferrokinetics in man. Medicine (Baltimore). 49:17-53.

34. Alpen, E. L., and D. Cranmore. 1959. Cellular kinetics and iron utilization in bone marrow as observed by ${ }^{59} \mathrm{Fe}$ radioautography. Ann. NY Acad. Sci. 77:753-65.

35. Ley, T. J., N. P. Anagnou, C. T. Noguchi, A. N. Schechter, J. DeSimone, P. Heller, and A. W. Nienhuis. 1983. DNA methylation in globin gene expression in patients treated with 5-azacytidine. In Globin Gene Expression and Hematopoietic Differentiation. G. Stamatoyannopoulos and A. W. Nienhuis, editors. Alan R. Liss, Inc., New York. 457-474.

36. Byrd, A. T. 1984. DNA methylation-how important in gene control? Nature (Lond.). 307:503-504.

37. Tanaka, K., E. Appella, and G. Jay. 1983. Developmental activation of the $\mathrm{H}-\mathrm{II} \mathrm{K}$ gene is correlated with an increase in DNA methylation. Cell. 35:457-465.

38. Ley, T. J., Y. Chiang, D. Haidaris, N. P. Anagnou, V. Wilson, and W. F. Anderson. 1984. Regulation of human globin genes in mouse erythroleukemia cells. Proc. Natl. Acad. Sci. USA. 81:66186622.

39. Papayannopoulou, T., A. Torrealba-de Ron, R. Veith, G. Knitter, and G. Stamatoyannopoulos. 1984. Arabinosylcytosine induces fetal hemoglobin in baboons by perturbing erythroid cell differentiation kinetics. Science (Wash. DC). 224:617-619.

40. Dover, G., S. Charache, and S. Boyer. 1978. Individual variation in the production and survival of $\mathrm{F}$ cells in sickle cell disease. N. Engl. J. Med. 299:1428-1435. 